\title{
IN SEARCH OF THE OPERATIC ARCHIVES OF GIUSEPPE BUSTELLI
}

\author{
MARC NIUBO \\ Univerzita Karlova v Praze
}

Izvleček: Obširne aktivnosti impresarija Giuseppa Bustellija, ki je v sezonah 1764/65-1777/78 uprizarjal opere $v$ Dresdnu in v Pragi, so prispevale k oblikovanju obsežnih glasbenih zbirk in kroženju gradiva po srednji Evropi. Nedavne identifikacije nekaterih Bustellijevih partitur odpirajo nova obzorja $v$ raziskavah opere osemnajstega stoletja $v$ Pragi in $v$ Dresdnu.

Ključne besede: opera 18. stoletja, Giuseppe Bustelli, Pasquale Bondini, glasbene zbirke.

\begin{abstract}
The exceptional activities of the impresario Giuseppe Bustelli, who performed operas in Dresden and Prague from 1764/65 to 1777/78, brought about the formation of large music collections and the circulation of materials within Central Europe. New identification of some of Bustelli's scores opens up further possibilities for research on eighteenth-century opera in Prague and Dresden.
\end{abstract}

Keywords: eighteenth-century opera, Giuseppe Bustelli, Pasquale Bondini, music collections.

The important political and economic changes in European society during the eighteenth century also affected the destiny of Italian opera in many ways. In particular, the success and the very shape of mid-century dramma giocoso, or, more colloquially, opera buffa, should be viewed in direct relation to the changing social structure of many European cities, the spread of the ideas of the Enlightenment, an increase in commercial activity and improved communications and transport. Similarly, as European theatrical routes became denser and more frequently used, the demand for new titles and new scores increased. Indubitably, the diffusion of Italian opera, especially opera buffa, during the eighteenth century considerably modified the importance and the actual production (copying, selling, preservation) of operatic scores themselves. ${ }^{1}$

As regular opera performances for paying audiences became the norm during the second half of the century, the system of teatro impresariale (or impresa) became widely established. Whether or not he rented his theatres, the impresario became a central figure

This article originated as a part of the grant project The Italian opera at the Thun Theatre in Prague (1781-1784), Grant Academy of the Czech Republic, No. 13-14789P.

1 Piperno, "Il sistema produttivo," 59-71. 
of the operatic enterprise, placing singers, musicians, poets, composers etc. under contract and usually also bearing the entire financial risk. The sheet music for the performances usually belonged to the impresario, unless he worked as a kind of intermediary for another interested party such as an academy, a society of proprietors or, more frequently, a court. The musical materials of impresarios working in municipal theatres, especially those hosting itinerant companies, have survived only in isolated cases, and then only as single items. In general, operatic productions are more frequently attested by libretti, which were usually printed in hundreds of copies, were relatively cheap, and were therefore more likely to be held by private libraries. In contrast, musical collections holding sources directly connected with specific theatrical performances (as opposed to memorabilia or collectors' items) are more often preserved in the archives of (former) court theatres or, more generally, when the productions were to some degree under the control of the local political authorities.

Many of the characteristics just described come together perfectly in the history of Italian opera in Prague in eighteenth century. In this study I would like to concentrate on some lesser-known features of the Prague operatic impresa and particularly on the complicated, yet interesting, situation regarding sources and their circulation. Despite some important findings presented below, the whole text is best understood as an interim report on ongoing, long-term research.

The rich operatic traditions of Prague in the eighteenth century are documented mostly by printed libretti preserved today in several libraries in the Czech Republic and abroad. The destinies of several opera impresarios working in Prague - e.g., Antonio Denzio and Giovanni Battista Locatelli - may be considered textbook cases: ${ }^{2}$ a constant battle, often lasting many years, to win the favour of audiences, ending in a prison sentence or flight to another country - these are well-known scenarios (mirrored even in the libretti of comic operas), that certainly give us a little hope of finding some musical scores. A very different case, however, is that of Giuseppe Bustelli, a successful Italian merchant, who acquired the Prague Theatre in Kotzen in a hereditary lease in 1764. ${ }^{3}$ Further, in 1765 Bustelli was engaged by the Dresden court to provide regular performances of Italian opera buffa in Moretti's Theatre (Kleines kurfürstliches Theater), which was to become the city's main stage for several decades. By renewing his contracts with the court Bustelli managed to maintain regular opera performances up to the outbreak of the War of the Bavarian Succession in 1778. This led to a rather unusual situation where a single impresario managed not only two theatres in two different cities but also ones in two different states and operating under quite different conditions. Bustelli established two separate Italian companies and performed a similar repertoire in both cities, the main difference being that Prague was favoured in addition with opera seria productions, whereas in Dresden only opera buffa was staged. ${ }^{4}$

This remarkable interconnection lasted for twelve years and inevitably affected the

2 For the most up-to-date biographies of Denzio and Locatelli, see the respective entries in Jakubcová, Theater in Böhmen, 146-151 and 394-398.

3 Ibid., 91-95.

4 Niubo, "Italian Opera between Dresden and Prague," 58-73. 
operatic undertaking in many ways. Singers as well as composers (e.g., Domenico Fischietti, Antonio Boroni) migrated from one city to the other; the repertoire was partially shared, as were the actual sheet music and the libretti. Undoubtedly, this situation was favourable not only to Bustelli but to the health of opera in both cities in general, since it made for a constant supply of new titles and relatively regular performances. Nevertheless, Bustelli, aware of the uncertainty governing the fortune of theatres, continued to make every effort to find new outlets. Notwithstanding his secure position in Prague and Dresden, he brought his companies to Carlsbad (1765), Leipzig (various years), Hamburg (1770), Brunswick (1770-1772, 1777) and even Ljubljana $(1766,1769){ }^{5}$

The situation changed in spring 1777 , when he stopped giving operatic performances in Prague, most probably because he planned to try his luck in Vienna. At this time Joseph II was intervening decisively in theatrical matters. In the course of the three years 1776-1778 the Italian company performing in the Burgtheater was dismissed, the Kärtnertortheater was offered for rent and the Burgtheater proclaimed a Nationaltheater (with a German company producing both singspiels and dramas). Bustelli, although he still had control of the Prague Kotzen Theatre, which he rented out to German actors, concentrated on his Viennese impresa. Possibly on account of his official engagement in Dresden, Bustelli's name does not appear in Viennese libretti until 1779, although singers from his former Prague company had been giving performances there since spring $1777 .{ }^{6}$ His efforts continued until 1780, when they were interrupted by the closure of theatres following the death of the Empress Maria Theresa in November. The theatres reopened on 21 January $1781 ;^{7}$ however, Bustelli's own death came soon afterwards, on 2 March 1781.

When an inventory was made of Bustelli's estate in Prague in April 1781, he was shown to have been a rich man with many possessions, including a large collection of theatrical costumes and sheet music. ${ }^{8}$ The inventory lists some 159 musical items, usually with the name of the author and the title given in Italian and/or German. Besides contemporary operatic scores (forty serious operas and ninety-seven opere buffe), there are also instrumental and vocal parts, printed libretti, cantatas, separate operatic numbers, oratorios and some unidentifiable pieces. The complete list is certainly impressive; however, the number of operas mentioned must surely be incomplete. In Prague alone Bustelli produced at least thirty further operas not included in the list, not to mention many others staged in Dresden and Vienna. Nevertheless, the inventory is of considerable importance: it demonstrates some of the dramaturgical strategies of the impresario, lists several titles of operas that were possibly never performed, and also points to some interesting unknown sources that tell us something about the impresario's contacts and choices. ${ }^{9}$

At the same time, this lengthy inventory makes the question of the later history of

5 Jakubcová, Theater in Böhmen, 92-94; Kokole, "1773 production," 254.

6 Deutsch, "Das Repertoire der höfischen Oper," 399. See also below.

7 Hadamowsky, Die Wiener Hoftheater, 10.

8 Pokorný, "Josef Bustelli," 85-111.

9 For instance, Lucrezia romana in Constantinopoli, one of the early operas of Carlo Goldoni set to music by Giacomo Macari. See Pokorný, "Josef Bustelli," 94-95. The inventory will be the subject of further evaluation in a forthcoming study. 
Bustelli's music that much more pressing and problematic. The document itself is rather cryptic. Towards the end, before the final valuation and the signatures of the civic officials, mention is made of a group of eighteen comic operas that is to be sold to Michele Patrassi, a former singer with Bustelli in Prague and Dresden. ${ }^{10}$ Most probably, Patrassi bought these operas even before the official auction took place in July of that year, when some 140 musical items were offered for sale. In the inventory, however, there is no further mention of what became of them, and, judging from this document alone, it seems that the only substantial purchase made during the auction was by Bustelli's colleague Pasquale Bondini, who bought the entire costume stock for the considerable sum of 4100 gulden. ${ }^{11}$ Nevertheless, as other documents reveal, Bustelli also left considerable debts, and during the following months and years there were certainly several other transactions that similarly involved the impresario's music (see below). Judging from the surviving documents in Vienna, the settlement of his estate concluded only in March $1790 .{ }^{12}$

When one searches for the routes taken subsequently by the music, the most obvious path leads to Michele Patrassi. Patrassi, together with a former dresser in Bustelli's employ named Luigi Simoni, established an opera company on behalf of the court of Brunswick, probably just after the impresario's death or even some months before. The titles of the operas Patrassi bought in Prague are not stated in the inventory. However, their identification is not entirely impossible, since a considerable portion of the Brunswick court music archives has been preserved and is now accessible in the Niedersächsisches Staatsarchiv in Wolfenbüttel. ${ }^{13}$ In 1998 Alena Jakubcová analysed the modern printed catalogue of the court music collection and proposed a list of ten scores that were most probably bought in Prague in $1781 .{ }^{14}$ During my own research in Wolfenbüttel I was able to confirm this supposition in most cases, and to identify further scores that can be reliably linked to Prague as place of origin or adaptation. Although some of the scores bought by Patrassi in 1781 are certainly missing today, the extant collection nevertheless includes at least eleven titles that came from Prague either through the Bustelli estate or in some other way. ${ }^{15}$ Since the theatrical links between Brunswick and Prague had been active since

${ }^{10}$ Prague, Národní archiv (CZ-Pa), ms. 1203, fol. 461; Pokorný, “Josef Bustelli,” 104.

${ }^{11}$ Pokorný, "Josef Bustelli," 104.

${ }^{12}$ The surviving documents concerning the legal proceedings in Vienna contain no information about Bustelli's music, nor, surprisingly, any mention of his Nachlass in Prague, although the process of settling his estate was apparently coordinated. I am grateful to Dr Hubert Reitterer for sharing with me his research in Viennese archives. See also Jakubcová, Theater in Böhmen, 94.

${ }^{13}$ Kindler, Findbuch zum Bestand Musikalien.

${ }^{14}$ Jakubcová, "Z Prahy až k severní ŕíšské hranici," 161. A few hints concerning the provenance of the sources are already given in Kindler, Findbuch zum Bestand Musikalien.

${ }^{15}$ On the basis of both external (covers, papers, handwriting) and internal evidence, the following scores have provisionally been identified as having some connection with Prague: P. Anfossi, L'avaro (46 Alt, Nr. 90-92); P. Anfossi, Il geloso in cimento (46 Alt, Nr. 70-72); P. Anfossi, La vera costanza (46 Alt, Nr. 184-185); F. Bertoni, Le pescatrici (46 Alt, Nr. 66); D. Fischietti, La morte d'Abel (46 Alt, Nr. 157); D. Fischietti, La donna di governo (46 Alt, Nr. 452-454); D. Fischietti, Il dottore (46 Alt, Nr. 45); G. Gazzaniga, La vendemmia (46 Alt, Nr. 220-221); P. A. Guglielmi, La sposa fedele (46 Alt, Nr. 113-115); G. Paisiello, L'avaro deluso (46 Alt, Nr. 29-30); G. Paisiello, La frascatana (46 Alt, Nr. 134-135). 
the late $1740 \mathrm{~s},{ }^{16}$ the total number of such scores is likely to be somewhat higher, although more detailed investigation of the material awaits further research.

The next clues lead us to Vienna. After Bustelli's departure from Prague in 1777 most of the members of his former company, including the tenor and composer Vincenzo Righini and the librettist Nunziato Porta, ${ }^{17}$ moved to the Austrian capital. Their first performances included the repertoire previously staged in Prague: e.g., Righini's La vedova scaltra and Il convitato di pietra, both with librettos by Porta. As the situation in Vienna was rather uncertain for Italian artists (see above), Porta, together with his wife, the singer Metilde Bologna, went to Venice, where he provided libretti for Giuseppe Sarti and Pasquale Anfossi. ${ }^{18}$ Next year, however, he was back in Vienna and apparently remained there until Bustelli's death in 1781, when he and his wife finally received an appointment in Esterháza, where they joined other colleagues from Prague. ${ }^{19}$

In Esterháza Porta became a Theaterdirektor with many duties including stage direction, wardrobe management and even action as a middleman regarding operatic scores and music copying for the court theatre or for Haydn himself. In this way the Esterháza music archives (today housed in the National Szechényi Library in Budapest), acquired many operas, some of these being connected with Porta's previous engagements. The acquisition of materials from Bustelli was all the more advantageous as the theatre archives in Esterháza had largely been destroyed by fire in 1779 and Haydn was in great need of new scores. ${ }^{20}$ The first contact probably occurred already during Bustelli's lifetime: in 1780; however, the majority of his materials came to Esterháza after his death. As early as September 1781 eight titles from Bustelli's estate were bought and sent to Esterháza via Peter Bianchi, the "Joseph Bustellischer Executor Testamenti" in Vienna. ${ }^{21}$ Since three of these operas were incomplete, only five titles were actually retained and paid for, the remainder being returned. What is more surprising and important is that some of these operas, notably Il cavaliere errante (by Traetta) and Orlando paladino (by Guglielmi), were works that Porta had already been trying to obtain from Brunswick - he cancelled his request only after the scores became available at a more favourable price following the auction of Bustelli's music in Prague. ${ }^{22}$ This is not, however, the only proof of links between the former colleagues and members of Bustelli's troupes in Prague and Dresden, who apparently entered into some kind of agreement (or arrangement) in order to take over control of the various theatrical imprese (Prague, Dresden, Leipzig, Brunswick) once held by Bustelli.

16 Jakubcová, “Z Prahy až k severní říšské hranici,” 163-164.

${ }^{17}$ Porta, today remembered mostly as Joseph Haydn's librettist, almost certainly began his career in Italy (Rome?). However, his first documented libretti came from Prague, where he worked from autumn 1773 or at latest from 1774.

${ }^{18}$ I contratempi and L'Americana in Olanda, both staged in autumn 1778 at the Teatro San Samuele.

${ }^{19}$ Bartha and Somfai, Haydn als Opernkapellmeister, 168 and 176.

${ }^{20}$ Ibid., 41 and 81.

${ }^{21}$ Ibid., 96.

${ }^{22}$ Ibid., 97. Since the original receipt does not state the operas' titles, Bartha and Somfai suggest that the three further items were the operas performed in Esterháza in 1782: M. A. E. Grétry, Zémire et Azor; A. Salieri, La fiera di Venezia; G. Paisiello, L’innocente fortunata. 
In contrast to the collection in Brunswick, that of Esterháza (because of its importance for Haydn research, obviously) has already been the object of extensive and detailed investigation. Consequently, the presence there of sources from Dresden is relatively well known, even if their total number is rather uncertain; but their connection with Bustelli has largely been neglected and, more particularly, no full identification of the materials from Prague has yet been undertaken. ${ }^{23}$ The most eloquent proof of the presence of Prague materials is unquestionably the signature "Strobach" on the first violin part of Guglielmi's Il ratto della sposa, ${ }^{24}$ and "Bondini" on the particello of Polidoro from the same opera, ${ }^{25}$ which was performed by Bustelli in Prague in summer 1766 (and again in 1775). ${ }^{26}$ Moreover, some of the watermarks, papers and copyists' handwritings point to Prague as the place of origin or adaptation of some of the materials. The total number of operas associated with Bustelli is still to be determined, since they often travelled several times across central Europe before finding a permanent home in Esterháza, although we can already identify eighteen titles with some certainty. ${ }^{27}$

An examination of the sources from Brunswick and Esterháza is highly revealing. However, to understand more fully the relationship between the various sources and their circulation, at least one further piece of the whole puzzle has to be briefly discussed: namely, Dresden. After establishing two opera companies Bustelli had also to establish two music archives: one for Dresden and one for Prague. While there is evidence of material being transferred from one city to the other (as in Il ratto della sposa, discussed above), this should be regarded as an exception rather than the rule. It would have been impossible to work with a single collection in both cities, let alone to run several oneoff theatre seasons in Leipzig, Brunswick and elsewhere. This assumption is further confirmed by both the inventory of Bustelli's estate, where some titles are recorded as having two scores, and also by the Dresden operatic sources, today mostly preserved in the Sächsische Landesbibliothek - Staats- und Universitätsbibliothek Dresden (SLUB).

${ }^{23}$ On the basis of the work of Bartha and Somfai and her own research in Dresden, Ortrun Landmann was probably the only scholar to suggest that Bustelli was responsible for the purchase of Dresden scores by Esterháza. See Landmann, "Die Dresdner Haydn-Quellen,” 525n25.

${ }^{24}$ Starting in the 1770s, Joseph Strobach was the first violinist of the Prague theatre orchestra, later to be remembered also as its “music director." See Jakubcová, Theater in Böhmen, 672.

${ }^{25}$ Both names were carefully recorded by Bartha and Somfai in their monumental work, albeit without further questioning of the origin of the parts. See Bartha and Somfai, Haydn als Opernkapellmeister, 269-270.

${ }^{26}$ The opera was performed also in Dresden in the same year (1766); however, the presence of Strobach's name as well as the structure of the score prove that it travelled between Dresden, Prague and Esterháza. More details are to be published in a special study.

${ }^{27}$ G. Avossa, Il ciarlone (OE 101); M. Bernardini, Amore e musica (OE 70); P. Anfossi, Il curioso indiscreto (OE 35); M. A. E. Grétry, Zémire et Azor (OE 7); P. A. Guglielmi, L'impresa d'opera (OE 65); P. A. Guglielmi, Il ratto della sposa (OE 66); J. Mysliveček, Farnace (OE 73); J. G. Naumann, Le nozze disturbate (OE 16); B. Ottani, Amore senza malizia (OE 74); G. Paisiello, Don Anchise campanone (OE 78); N. Piccinni, L'Americano (OE 80); V. Righini, Il convitato di pietra (OE 84); V. Righini, La vedova scaltra (OE 78); A. Salieri, La fiera di Venezia (OE 10); A. Salieri, La secchia rapita (OE 87); G. Sarti, I contratempi (OE 30); T. Traetta, Il cavaliere errante (OE 96); and the pasticcio Circe o sia L'isola incantata (OE 57). 
A large part of these Dresden sources can be divided into two main groups according to their provenance: the Hofarchiv or the Opernarchiv. ${ }^{28}$ At first sight, the distinction is clear and functional. Whereas the Hofarchiv collection consists mostly of calligraphic scores written by court copyists, bound in decorated leather and lacking any signs of use, the Opernarchiv collection includes a variety of sources, scores and parts, written in different places and often with various adaptations. Most of them, but not all, were used for performances in Dresden. From the time of Bustelli's impresa onwards it became a rule to make a presentation copy of every single opera for deposit in the Hofarchiv. Not all the operas staged, however, survive in the form of two scores: many lack either the court copy or the performance one, while some works exist in three copies originating from the Opernarchiv alone. Moreover, the Hofarchiv collection also contains copies of operas performed not in Dresden but in Prague (or other places). ${ }^{29}$

Besides the particular interest of several members of the Elector's family in music and opera, one of the main reasons for this abundance and diversity of materials in Dresden is precisely the double impresa of Bustelli - his activity in two different cities over so many years. Whenever Bustelli acquired a score from Italy or elsewhere, he usually had at least one extra copy made so at to be able to perform the opera in both locations at any time. In this way, many operas were deposited in Dresden, though never performed here. However, as some materials prove, the second set of music was not always to hand, and under those circumstances a copy from Dresden was used for performance in Prague or vice-versa, and even for performance in Vienna in the late 1770s. Paradoxically, the present-day abundance of operatic scores in Dresden makes the two questions of their origin and connection with Prague more puzzling. Although many of these sources are carefully described and catalogued in the RISM A/II database, and while some of the Prague copies have been already identified by Ortrun Landmann, the process of making a precise identification of the entire archive is far from complete. ${ }^{30}$

Despite the importance of these new findings, especially for further research into Prague opera, the bulk of Bustelli's music collection, as attested by the estate inventory, remains largely unknown. ${ }^{31}$ Our attention should thus turn to Bustelli's closest colleague and "heir," Pasquale Bondini, who recommenced performances of Italian opera in Prague in autumn $1781 .^{32}$ Although there is no direct evidence for such a claim, there is a strong

${ }^{28}$ Landmann, "Das Dresdner Opernarchiv in der SLUB," 65-78; Landmann, Die Dresdner italienische Oper, 1-13.

${ }^{29}$ For instance, Bellerofonte by Josef Mysliveček and Semiramide by Giovanni Marco Rutini.

${ }^{30}$ Landmann, "Das Dresdner Opernarchiv in der SLUB," 88 and 91.

${ }^{31}$ Individual items are found in other archives (e.g., Bibliothèque nationale de France in Paris and Fürst Thurn und Taxis Hofbibliothek und Zentralbibliothek in Regensburg), and there is also a set comprising some ten scores, held by the National Museum in Prague, which bear marks indicating Bustelli's possession. However, this material is temporarily inaccessible and will therefore be described in a separate study focusing on Bustelli's inventory and estate.

32 A long-time singer with Bustelli and his co-director in Dresden, Bondini went on to develop a career as an impresario, starting with a German theatre company based in Dresden in 1777 but also giving performances in Leipzig and Prague. In autumn 1781 Bondini recommenced public performances of Italian opera in count Thun's Theatre in Prague, later moving to the newly 
probability that Bondini acquired not only Bustelli's wardrobe but also a portion of his sheet music and libretti. First, there is an item in the inventory described as "Ein packel von Musicalien allhier gelassen von $\mathrm{H}$. Bondini," ${ }_{33}$ which, if nothing else, testifies to the two colleagues' close relationship and the circulation of materials between them. Second, at least eleven operas performed in Prague during the 1780s by Bondini were already in the possession of Bustelli. ${ }^{34}$ Third, when staging some of these operas Bondini used libretti that had been printed by Bustelli back in Dresden during the $1770 \mathrm{~s} .{ }^{35}$ Moreover, according to the estate inventory, a large lot of over 11,000 unbound libretti was bought by an unknown purchaser for a price of seventy five gulden and thirty kreuzer. Such a large purchase might have been of interest to a paper manufacturer, although for an opera impresario it would have been very convenient, to say the least.

There is evidence that this collaboration between Prague and Dresden and a twoway traffic in musical materials continued for the next few decades, although over time the various theatre companies passed into different hands. Andrea Bertoldi took charge of the Italian operatic productions in Dresden, where Bondini's wife Catarina sang until 1785. Pasquale Bondini directed not only the Prague Italian opera company (with which he several times visited Leipzig) but also the German theatre company based in Dresden, which certainly facilitated the transfer of scores. Unfortunately, there is no similar evidence of materials used by Bondini and his partner and successor Domenico Guardasoni, who managed the Italian opera in Prague up to his death in 1806. No inventory of the latter's estate has survived, and it can only be supposed that his musical archives were taken over by the new director, Carl Liebich. ${ }^{36}$ By that time, however, the nature of both the Italian opera and the operatic impresa had changed considerably. In Italy as well as other countries the semi-seria genre was in the ascendant, and the opera buffa in Prague (and elsewhere in Central Europe) was being replaced by German (or Czech) singspiels and farces. For financial reasons, the new director of the Estate Theatre, Carl Liebich, was excused for not establishing an Italian company for the new season, and this became the rule for the rest of the century. ${ }^{37}$ No doubt, the repertoire of Bondini, or even Bustelli, had become very outmoded by 1806 , so it is quite likely that most of the music, even if it had passed into the possession of Liebich, was sooner or later sold as unserviceable old paper.

built Estates Theatre. For a recent summary of Bondini's activities, see Jakubcová, Theater in Böhmen, 61-64; and Woodfield, Performing Operas for Mozart (with many new details, albeit somewhat imprecise where Prague is concerned).

${ }^{33}$ Pokorný, "Josef Bustelli," 98.

${ }^{34}$ G. Gazzaniga, Andromeda (1781); P. Anfossi, Il curioso indiscreto (1782); G. Gazzaniga, La vendemmia (1782); P. Guglielmi, Gl'intrichi di Don Facilone (1782); P. Anfossi, Isabella e Rodrigo (1783); G. Astarita, Circe ed Ulisse (1783); G. Gazzaniga, L'isola d'Alcina (1784); J. G. Naumann, Ipocondriaco (1784); G. Paisiello, L'Avaro deluso (La discordia fortunata, 1784); G. Paisiello, La frascatana (1784); P. Anfossi, La vera costanza (1785).

${ }^{35}$ For instance, La frascatana and Gl'intrichi di Don Facilone; see above.

${ }^{36}$ Ludvová, Hudebni divadlo v českých zemích, 306-310.

${ }^{37}$ The Italian repertoire became reduced in size and was staged and adapted in either German or Czech. See Teuber, Geschichte des Prager Theaters; Niubo, "Italská opera ve Stavovském divadle," 315-327. 


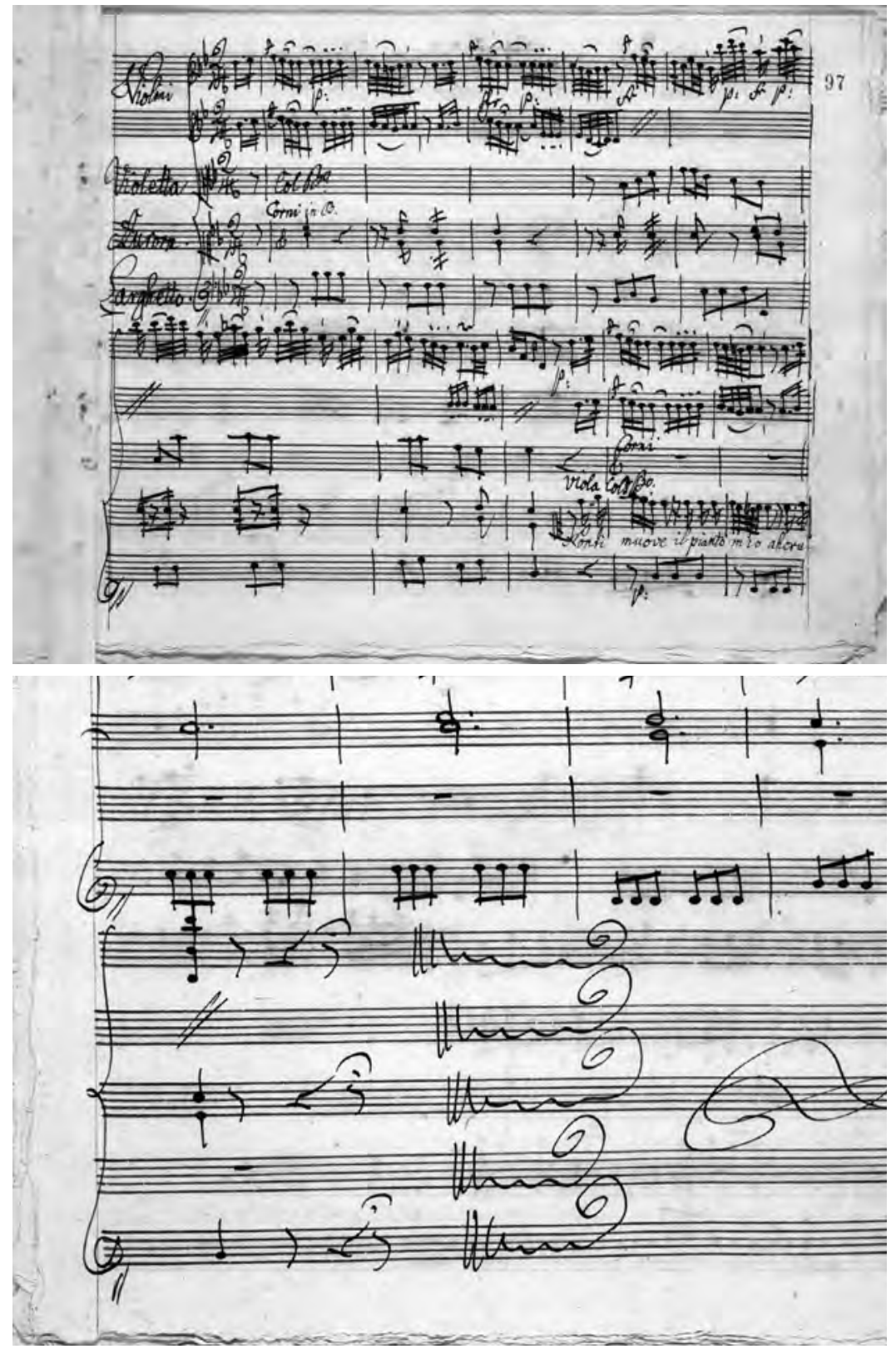

Figures 1 and 2 The script of the Prague coyist. Transpposed aria in P.

Guglielmi's Il ratto della sposa (Budapest, Országos Széchényi Könyvtár, OE 66; reproduced with kind permission). 
It is thus, perhaps, a more than symbolic gesture if we now conclude our investigation with a brief remark on that most iconic work of Prague's operatic history: Mozart's Don Giovanni. Its Prague score witnessed not only the most glorious days of Italian opera in Prague but remained in use for performances there until the mid-nineteenth century. ${ }^{38}$

\section{Bibliography}

Bartha, Dénes, and László Somfai. Haydn als Opernkapellmeister. Budapest: Verlag der Ungarischen Akademie der Wissenschaften, 1960.

Deutsch, Otto Erich. "Das Repertoire der höfischen Oper, der Hof- und der Staatsoper." Österreichische Musikzeitschrift 24, no. 7 (1969): 369-421.

Hadamowsky, Franz. Die Wiener Hoftheater (Staatstheater) 1776-1966: Veröffentlichungen der Österreichischen Nationalbibliothek. Vol. 1, 1776-1810. Wien: Georg Prachner Verlag, 1966.

Jakubcová, Alena. "Z Prahy až k severní říšské hranici: cesty principálů a jejich repertoárových kusů ve druhé polovině 18. století.” Hudební věda 35, no. 2 (1998): 155-170. and Matthias J. Pernerstorfer, eds. Theater in Böhmen, Mähren und Schlesien. von den Anfängen bis zum Ausgang des 18. Jahrhunderts. Wien: ÖAW, 2013.

Kindler, Klaus. Findbuch zum Bestand Musikalien des herzoglichen Theaters in Braunschweig 18.-19. Jh. (46 Alt). Veröffentlichungen der Niedersächsischen Archivverwaltung, Inventare und kleinere Schriften des Staatsarchivs in Wolfenbüttel. Wolfenbüttel: Niedersächsisches Staatsarchiv, 1990.

Kokole, Metoda. “The 1773 Production of Piccinni's La buona figliuola in Ljubljana and Other Local Traces of Italian Operas in the Later Part of the 18th Century." In Niccolò Piccinni Musicista Europeo: atti del Convegno Internazionale di Studi, edited by Alessandrio di Profio and Mariagrazia Melucci, 253-263. Bari: M. Adda, 2004.

Landamann, Ortrun. Die Dresdner italienische Oper zwischen Hasse und Weber: ein Daten- und Quellenverzeichnis für die Jahre 1765-1817. Dresden: Sächsische Landesbibliothek Dresden, 1976.

-."Das Dresdner Opernarchiv in der SLUB." In Über das Musikerbe der Sächsischen Staatskapelle: drei Studien zur Geschichte der Dresdner Hofkapelle und Hofoper anhand ihrer Quellenüberlieferung in der SLUB Dresden, edited by Ortrun Landmann. Dresden, 2010. Accessed 5 January 2015. http://nbn-resolving. de/urn:nbn:de:bsz:14-qucosa-25559.

Ludvová, Jitka, ed. Hudební divadlo v českých zemích: osobnosti 19. století. Praha: Academia, 2006.

${ }^{38}$ The so-called Donebauer score, Prague, Knihovna Pražské konzervatoře, 1 C 276. This score has survived up to modern times only because of the fact that it became the personal [?!] property of Carl Thomé, the director of the Estate's Theatre during 1858-1864, and was later inherited by his daughter Anna Willhain. See Mozart, Don Giovanni, 32-33. 
Mozart, Wolfgang Amadeus. Don Giovanni. Neue Ausgabe sämtlicher Werke, Kritische Berichte, Serie II, Werkgruppe 5, Band 17, edited by Wolfgang Rehm. Kassel: Bärenreiter, 2003.

Niubo, Marc. "Italian Opera between Prague and Dresden in the Second Half of the 18th Century." In Musiker-Migration und Musik-Transfer zwischen Böhmen und Sachsen im 18. Jahrhundert, edited by Hans-Günter Ottenberg and Reiner Zimmermann, 58-73. Dresden: Technische Universität, 2012. Accessed 5 January 2015. http://www.qucosa. de/recherche/frontdoor/?tx_slubopus4frontend[id]=urn:nbn:de:bsz:14-qucosa-88008. . "Italská opera ve Stavovském divadle v první třetině 19. století." In Naše Itálie: stará i mladá Itálie v české kultuře 19. století, edited by Zdeněk Hojda, Marta Ottlová and Roman Prahl, 315-327. Praha: Academia, 2012.

Piperno, Franco. "Il sistema produttivo fino al 1780.” In Storia dell'opera italiana, pt. 2, vol. 4, 59-71. Torino: EDT, 1987.

Pokorný, Jiří. “Josef Bustelli a jeho hudební pozůstalost.” Miscellanea musicologica 33 (1992): 85-111.

Teuber, Oskar. Geschichte des Prager Theaters: von den Anfängen des Schauspielwesens bis auf die neueste Zeit. Vol. 3. Prag: A. Haase, 1887.

Woodfield, Ian. Performing Operas for Mozart: Impresarios, Singers and Troupes. Cambridge: Cambridge University Press, 2012. 


\section{PO SLEDEH OPERNEGA ARHIVA GIUSEPPA BUSTELLIJA}

\section{Povzetek}

Glasbeni arhivi opernih impresarijev, ki so v 18. stoletju vodili javne operne hiše, se kot celota do danes niso ohranili. Zato tudi zgodovino praškega opernega gledališča danes rekonstruiramo predvsem na podlagi ohranjenih tiskanih libretov. Razprava govori predvsem o izjemno bogatem obdobju, ko je praško operno hišo vodil italijanski impresarij Giuseppe Bustelli, ki je hkrati deloval tudi v Dresdnu (v sezonah 1764/1765-1777/78). V tem času je nastala velika zbirka glasbenega gradiva, poleg tega so njegovi glasbeniki krožili po vsej srednji Evropi. Sistematične raziskave v zvezi z delovanjem Giuseppa Bustellija in njegovih naslednikov v številnih opernih središčih, kot so Dresden, Praga, Dunaj, Esterháza in Brunswick, so njegova prizadevanja osvetlila z nove strani. Identificiranih je bilo tudi nekaj opernih partitur, ki jih je uporabljal za svoje predstave. V Brunswicku sta njegova bivša pevca Michele Patrassi in Luigi Simoni ustanovila leta 1781 svoje lastno podjetje, za predstave pa sta uporabljala tudi starejše Bustellijevo gradivo. Podobno je svojo kariero nadaljeval tudi Bustellijev libretist Nunziato Porta, ki je svojo poklicno pot skupaj s še nekaterimi kolegi iz Prage nadaljeval v kraju Esterháza. Tudi oni so še naprej uporabljali stare Bustellijeve partiture. Izmenjava partitur med Prago in Dresdnom je bila v času Bustellijevega delovanja v teh dveh mestih povsem običajna, zanimivo pa je, da se je ta izmenjava do neke mere nadaljevala tudi po impresarijevi smrti, ko je že ustaljeno uprizarjanje italijanskih oper v Pragi prevzel Pasquale Bondini. Razprava prinaša pregled novih dejstev, ki jih je prinesla zgoraj omenjena raziskava in ki odpirajo tudi vrsto novih vprašanj in možnosti za nadaljnje delo in raziskave opernega življenja v Pragi in Dresdnu v 18. stoletju. 